\title{
コネクショニストモデルの忘却を用いた 一般構造学習
}

\author{
正員石川畺 澄 (九州工大)
}

\section{A General Structural Learning of Connectionist Models Using Forgetting Masumi Ishikawa, Member (Kyushu Institute of Technology)}

The backpropagation through time, a learning algorithm for recurrent networks, has a drawback of being unable to provide structural information, such as locations of feedback loops in a network. I have previously proposed a structural learning algorithm with forgetting of link weights for hierarchical networks. By eliminating unnecessary links due to forgetting, the structural learning can generate a skeletal structure reflecting inherent regularity in training patterns.

Proposed here is a general structural learning algorithm with forgetting for recurrent networks by combining the above two algorithms. This algorithm can generate a skeletal structure for recurrent networks based on input and output sequences with no prior structural information.

Four kinds of Jordan networks are selected as typical examples of recurrent networks including feedback and self loops. The proposed algorithm can, in most cases, rediscover the original Jordan network structure solely from input and output sequences. This well demonstrates the effectiveness of the proposed algorithm in rediscovering the original network structure for recurrent networks.

キーワード：コネクショニストモデル,ニューラルネットワーク, リカレント. 構造学習, 忘却

\section{1.まえがき}

コネクショニストモデルあるいはニューラルネット ワークモデル(同義に使うことが多い(7) )で最も一般的 な構造は，任意のニニット間にリンクの張られている 密結合ネットワークである。階層的ネットワークやジ ョルダンのネットワーク(2)などはこの特殊な場合に相 当している。本論文では，フィードバックループや自 己ループを含む一般的な構造であるリカレントネット ワークの学習を扱う。

このリカレントネットワークの学習法として Williams らの通時的誤差逆伝播 (Backpropagation Through Time）学習などの方法が提案されている゙(3)cただ， これらによりリカレントネットワークの学習を行って も㭱とんどのリンタが残存するため，フィードバック ループや自己ループがどこにあるかという棈造情報が 明確にはならない。こ机らの構造情報は，得られたネ
ットワークを理解するうえで極めて重要である。この 事情は，階層的ネットワークで誤差逆伝播学盟(1)を行 っても，ほとんどのリンクが残存するため，必要な噯 れ層数や各層での隠れユニット数などの構造パラメー 夕が明確にならないのと同様である(4)。

著者は学翌の目的として, 入出力間の写像をネット ワーク上に再現するにとどまらず，訓練パターンに含 まれる規則を発見することが重要であると考えてい る。この考え方に従い, 忘却を用いた構造学習法を既 に提案した(4)。これは，階層的ネットワークを対象と し, 訓練パターンに内在する規則性の発見を目的とす る。すなわち、リンク重みに忘却を導入して不要なり ンクを消隇させることにより，規則性を反映した骨格 構造が出現する。この学習法には, 層数や隠れユニッ 卜数などの構造パラメータを試行錯誤的に探索する必 要がなく, 俱差逆伝播学習に比べて一般化能力が大き いなどの利点がある。 
本論文では，階層的などの構造に関する事前情報を 必要としないネットワークの新しい構造学習法を提案 し,これを忘却付き一般構造学習法と名づける の基本的アイデアは, 通時的䛊差逆伝播学習法と忘却 付き構造学習法を組合せた点にあり, 前者のレカレン トネットワークの学習と, 後者の構造の学習という二 つの利点を兼的備えた新しい学翼法である。

すべてのエニット間にリンクの張られた密結合ネッ トワークから出発して本手法による学習を行うことに より, 不要なリンクが忘却により消隇し，レカレント ネットワークの骨格構造を生成てきる。この骨格構造 の生成は，従来の方法では得られない大きな特長であ る。この特長により, 後述のようなネットワーク構造 の再発見が可能になる。

以下，第 2 章では通時的誤莁逆伝播学習法の概要を 述べる。第 3 章では忘却付き構造学習法の概要を述べ ると共に, 両者を組合せた忘却付き一般構造学習法に ついて説明する。更に，この手法の有効性を確かめる ため, 第 4 章で入出力系列に基づくジョルダンネット ワーク構造の再発見を幾つかの例について行う。

\section{2. 通時的誤差逆伝播学習法}

通時的誤差逆伝播学習法 ${ }^{(3)}$ は, 外部入力系列と一部 のユニット（可視ユニットと呼ぶ）の目標出力系列が 与えられた場合，これらを再現するリカレントネット ワークを求めるための学習法である。

基本的には，図1（a）のようなリカレントネットワ 一クに対し，各時刻ごとにそのコピーを用意し，これ を時刻順に並べて (b)図のような階層的ホットワーク を構成する。ここで，西る時刻のユニットが，次の時 刻のすべてのユニットと結合されているネットワーク が密結合ネットワークに相当する。この場合, $n$ 個の ユニットに対して, 自己ループも含め $n^{2}$ 本のリンタ が存在する。各時刻のユニット群に外部入力が加えら れ，また各時刻の可視ユニットに目標出力が与えられ ている。なお,リンクで結合された次時刻のユニット に活性度が伝播するのに要する時間は, どのリンクも 同一と仮定している。

時間軸方向に展開された図 1（a)では，各階層が時 刻に対応するという特殊性はあるものの, 基本的には 誤差逆伝播と類似の学習が可能である。いま時刻 $t_{0}$

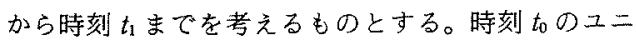
ット活性度および同時刻の外部入力が，時刻 $t_{0}+1 の$ ユニットに伝播するという形で, 活性度が順次時間軸 方向に伝播する。逆に, 時刻 $t_{1}$ の出力誤差加同時 刻のユニットの誤差が定まり，次にこの䛊差と時刻

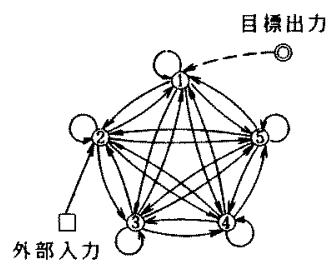

(a) 原ネットワーク梅造

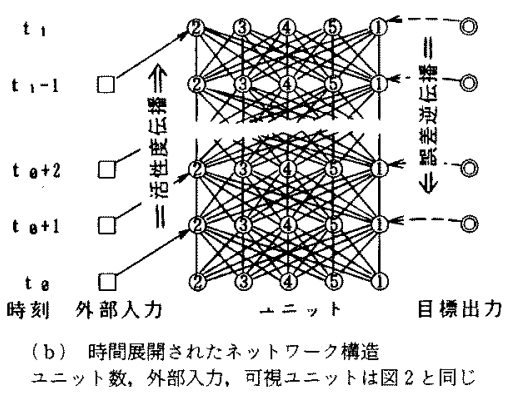

図 1 通時的愦差逆伝播に括ける ネットワーク構造

Fig. 1. Network structure in the backpropagation through time.

$t_{1}-1$ の出力誤差から, 時刻 $t_{1}-1$ のュニットの䛊差

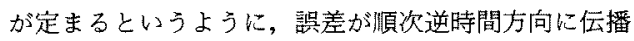
する。

この逆方向への呪差の伝播は以下のように定式化で きる。各時刻 $t$ での第 $k$ ユニットの出力䛩差 $e_{k}(t)$ は,

$e_{k}(t)=\left\{\begin{array}{ll}d_{k}(t)-y_{k}(t) & ; k \in T(t) \\ 0 & ; \text { その他 }\end{array}\right\}$

ただし， $d_{k}(t)$ : 時刻 $t$ での目標出力,

$y_{k}(t)$ : 最刻 $t$ での出力, $T(t)$ : 時刻 $t$ での

可視ュニット集合

時刻 $t_{0}$ から $t_{1}$ までの最小化すべき評価関数 $J$ は,

$$
J\left(t_{0}, t_{1}\right)=1 / 2 \sum_{t=t_{0}+1}^{t_{1}} \sum_{k} e_{k}(t)^{2}
$$

各ユニットの誤差 $\delta$ は次のように再帰的に求め得る。

$$
\begin{aligned}
& \varepsilon_{k}\left(t_{1}\right)=e_{k}\left(t_{1}\right) \\
& \delta_{k}(t)=f^{\prime}\left\{s_{k}(t)\right\} \varepsilon_{k}(t) \\
& \varepsilon_{k}(t-1)=e_{k}(t-1)+\sum_{m} w_{m k} \delta_{m}(t) \\
& \text { ただし， } f \text { : 各ユニットの出力閔数（ロジス } \\
& \text { ティック関数 }), f^{\prime}: \text { その微分, } s_{k}(t) \text { : 時刻 } \\
& t \text { での第 } k \text { ユニットへの入力量, } w_{m k} \text { : 第 } k \\
& \text { ユニットから第 } m \text { ユニットヘのリンク重み, } \\
& \delta_{k}(t) \text { : 時刻 } t \text { の第 } k \text { ュニットの誤荎 }
\end{aligned}
$$


(5)式吉辺第 1 項が時刻 $t-1$ における出力誤差, 第 2 熕が時刻 $t$ での各ュニットの誤差 $\delta$ を時刻 $t-1$ に逆伝播したものである。

(3) 〜 (5) 式に従って各時刻でのユニットの愦差 $\delta$ を求めると, 誤差逆伝播学習の場合と同様に, リンク 重みの修正值 $\Delta w_{m k}$ は次式で与えられる。

$$
\Delta w_{m k}=\eta \partial J / \partial w_{m k}=\eta \sum_{t=t_{0}+1}^{t_{1}} \delta_{m}(t) f\left\{s_{k}(t-1)\right\}
$$

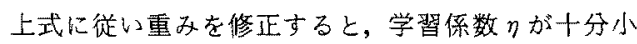
さい限り（2）式の評洒 $J$ が小さくなることは偏微分 の定義から明らかでろう。なお実際には一回前の重み 修正量も考慮に入れたいわゆるモーメンタ厶項を付け 加えることが多い(1)

\section{3. 忘却付き一般構造学習法}

忘却を用いる構造学習法は、リンク重みに忘却を導 入することにより，不要なユニットやリンクを消滅さ せ，ネットワーク中に骨格構造を形成する(4) この場 合の評価関数として次式を用いる。

$$
J=\sum_{i}\left(y_{i}-d_{i}\right)^{2}+\varepsilon^{\prime} \sum_{m, k}\left|w_{m k}\right|
$$

ただし，右辺第 1 項は出力誤差の自乗和であり，誤菱 逆伀播学習法における評洒である。第2 項はりンク重 みの絶対值和である。第 2 項は，重みが零になる点以 外では線形関数であり，学習の収束性などには悪影響 を与えない(4)(8) 微分すると, 繰返しごとの重みの修正量 $\Delta w_{m k}{ }^{\prime}$ が次 式で与えられる。

$$
\begin{aligned}
\Delta w_{m k} & =-\eta \partial J / \partial w_{m k} \\
& =\Delta w_{m k}-\varepsilon \operatorname{sgn}\left(w_{m k}\right)
\end{aligned}
$$

ただし， $\Delta w_{m k}$ : 誤差逆伝播学習法による重 み修正量, $\varepsilon\left(=\eta \varepsilon^{\prime}\right):$ 繰返しごとの忘却量, $\operatorname{sgn}(x): x$ が正で $1 ， x$ が負でー1，xが 0 で 0 をとる符号関数

できるだけ小さなネットワークを生成しようという 類似の学習法も幾つか提案されて扔り，これら諸手法 との比較は文献 (6)を参照されたい。

(1)〜 (6)式と (7) 〜 (8)式を組合せた，忘却付き 一般構造学習法がここでの提案である(5)。これにより 階㢞的ネットワークの場合と同樣に，忘却により不要 なリンクが消滅し，リカレントネットワータの骨格構 造が出現することが期待される。

なおここでの忘却は，図 1 で時刻が進むことによる 忘却ではなく，一つの系列を是示して一回の学習を行 い, 次回の学習までの間に各リンク重みが一定量減衰
するという意味での忘却である。

一般に入出力系列とリカレントネットワークとは一 対多の関係にあること虫明であろう。すなわち，入 出力系列が与えられると、これを再現するリカレント ネットワークは無数に存在する。この事情は, 階層的 ネットワークの場合も同様である。本手法は, 忘却の 働きにより，与えられた入出力系列を実現するネット ワークのうちで，できるだけ単純なネットワークを求 めるものである。なお学習の際, 極小値に陷ることも あるので，常に最小のネットワークが生成される保証 はない。しかし，次章の幾つかの例で示すように，極 小値に陷る可能性は経験的にはそれほど大きくない。

\section{4. 一般的構造の再発見例}

本章では幾つかのりカレントネットワークを取上 げ，その構造に関する事前情報を用いないで，ネット ワーク構造を構造学習により再発見する課題を报う。 すなわち，ある構造のネットワークに外部入力系列を 加之て出力系列を求め，これを目標出力系列と考之 る。これらの外部入力系列および目標出力系列だけに 基ついて，最も一般的な構造である密結合ネットワー クから出発して, 忘却付き一般構造学習により, 元の ネットワーク構造を再発見することを目的とする。

ここではリカレントホットワークの典型例として, フィードバックループや自己ループを含むジョルダン ネットワークを取上げる。以下の各例において, 図 1 のネットワークで十分な数のユニットを用意し，任意 の時刻 $t$ のニニット群と次の時刻 $t+1$ のユニット群 がすべて結合した密結合ネットワークから出発する。 これが，事前の構造情報を用いないことに相当してい る。またりンクの初期重みは乱数で与える。

[例 1] 単純なジョルダンネットワーク：図 2(a) に示すジョルダンネットワークから得られた長さ 20 の外部入力系列坑よび目標出力系列だけに基づいて, 忘却付き一般構造学習を行う。同図には○内にユニッ 卜番号を、リンクにはその重みの值を併せて示してあ る。十分な数のユニットとして 1 時刻につき 5 個のユ

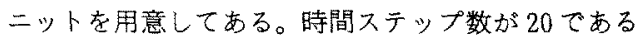
ので, 21 層のネットワークとなる。従って, ュニッ トの総数は 105 個 $(=5 \times 21)$ である。

外部入力ロはユニット(2)に入り，可視ユニット(1)の みが目標出力を与えら扎てる。外部入力としては, ランダムではないが相当大きく変動するデータを1系 列だけ用いた。複数個用いることももちろん可能であ る。な极外部入力からユニット(2)へのリンクの重みは 固定で 2 とする。外部入力の入るユニット(2), および 


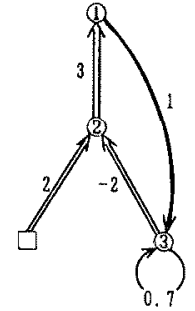

(a) 正しい棈造

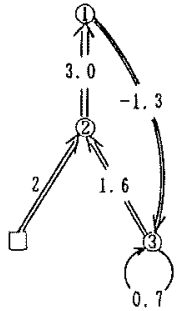

(b) 学琶結果 $(ケ-ス 1)$

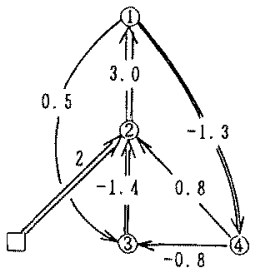

(c) 学習結果 (ケース2)

ソンクの太さははほリンク雷みの絶対值に比例する

図 2 単純なジョルダンネットワークの構造再発見

Fig. 2. Rediscovery of a simple Jordan network.

可視ユニット(1)以外は，どのユニットが何に使われる か, あるいは消隇するか戊前にはわからず，学習の 結果により定まる。ここでュニットが消隇するとは， 当該ユニットへのすべてのリンクおよび当該ユニット 加らのすべてのリンクが忘却により消隇することを意 味する。な敌図2では若いユニット番号が使われるよ う番号を付け替えている。

3種類の暴なる初期りンク重みから出発して学習を 行った結果をそれぞれケース $1 ， 2 ， 3$ と呼ぶ。なお 学習係数 $\eta=0.1$, モーメンタム係数 $\alpha=0.2$, 忘却量 $\varepsilon=10^{-4}$ を用いた。学習に要した繰返し回数は 35,000 $\sim 50,000$ 回であり，出力譟差は $1 \%$ 以下と十分小さく なった。ケース1を(b)図に示す。同図では余分の二 つのユニットが消滅し, 元の構造を再発見できたこと がわかる。得ら机たりンク重みの值は (a)図の正解と は異なっているが，これは何の支障もない。なぜなら ば、ユニット(1)からユニット(2)への伝達特性を定めて も, 中間のユニット(3のとり得る值に関しては自由度 が残っているからである。実際，(a)図上(b)図は， 状態ユニット(3)の役割が異なっているだけで, 入力端 (2)と出力端(1)から見る限り全く等価である。

ケース 2 を $(\mathrm{c})$ 図に示す。これは正解とは異なる構 造であるが，(a)図でのユニット(3)の役割が(3)(4)の 二つに分離したと考えれば理解できる。ケース 3 は重 みの值は異なるものの，(b)図と同型の構造である。 なお，1時刻について 5 個よりも多くのユニットを用 いて構造学習をしても, 消隇するユニット数が増える だけで，生成される骨格構造は不変である。

訓練用とは異なる新しい外部入力系列に対する出力

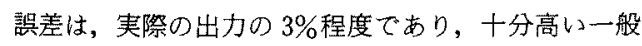
化能力が得られている。

ケース $1 の(\mathrm{~b})$ 図の場合, $25(=5 \times 5)$ 本のリンク中 4 本だけが残存している。これと同じ初期重みを用い

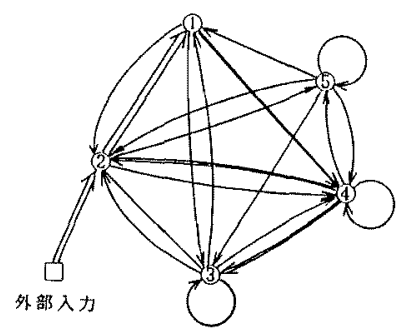

リンク重みの絶対倠が 0.1 以上のリンクのみを表示 図 3 通時的誤差逆伝播学習による単純な ジョルダンネットワークの学習例

Fig. 3. A learning result of a simple Jordan network by backpropagation through time.

て, 通時的誤差逆伝播学習を行った結果を図 3 に示 す。同図では，絶対值が 0.1 以上の重みを有するリン クのみを示す。それでも20本ものリンクが残存し, これから構造を読取ることは不可能である。リンクが 多いためりンク重みの表示は省略するが，概略の大き さはリンクの太さから推案できよう。

(例2) 複雑なジョルダンネットワーク：図 4(a) に示すジョルダンネットワークから得られた長さ 20 の外部入力系列抢よび目標出力系列に基づいて，その 構造を再発見する。1 時刻についてユニットを8個用 意してあり，外部入力口はユニット(3)に入り，ュニッ 卜(1)(2)のみが目標出力を与えられている。

3 種類の異なる初期重みから出発して学習を行っ た。な扔学習係数, モーメンタム係数, 忘却量, 外部 入力は例 1 と同じである。50,000 回の絽返し学習の結 果, 例 1 と同样に十分小さな出力誤差が得られた。結 果の一例を $(\mathrm{b})$ 図に示す。同図では余行の 2 個のュ二 ットが消隇している。他の二つのケースも、リンク重 みの值は異なるものの、これと同型の構造である。こ 


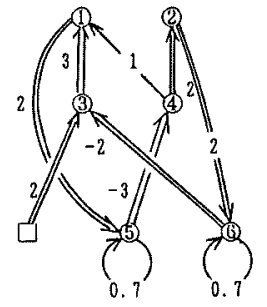

(a) 正しい構造

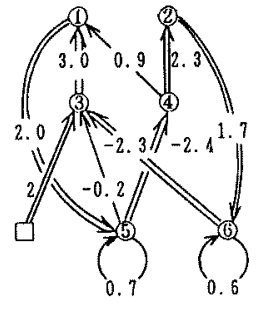

(b) 学習結果 (ケース1)
図 4 複雑なジョルダンネットワークの 構造再発見

Fig. 4. Rediscovery of a complex Jordan network.

れらはいずれも元の構造とほとんど同一であるが，ユ ニット(5)から(3)への一本のリンクが付加されている点 が異なる。これは，ユニット(5)からへのパスが元の 構造では 1 本であったものが, 構造学習の結果 2 本に なり表現が分散的になったためであり，最小構造では なく，極小値解が得られたのものと考えられる。しか しこの場合にも, 入力端(3)と出力端(1)(2)から見る限 り元のネットワークと等洒である。

[例 3] カスケードモデル：図 5（a)に示すカスケ 一ドモデル(2)から得られた長さ200外部入力系列お よび目標出力系列に基づいて，その構造を再発見す る。これはジョルダンの提案した制御のためのモデル であり，フォワードモデル部分（制御対象のモデルに 相当する部分で，ュニット(1)〜(3)）とコントローラ部 分 (4) (5)）から構成されている。このうちフォワー ドモデル部分はその構造およびリンク重みを既知とす る。1時刻についてユニットを 7 個用意してあり, 外 部入力口はユニット(4)に入り，ュニット(1)のみが目標 出力を与えれている。

3 種類の異なる初期重みから出発して学習を行っ た。な打学習係数, モーメンタ厶係数, 忘却量, 外部 入力洌 1 と同じである。31,000〜61,000回の繰返し 学舅により, 例 1 と同様に十分小さな出力誤差が得ら れた。結果の一例を(b)図に示す。同図では余分の二 つのユニットが消隇し，正解と同型の構造が得られ た。残りの二つのケースでも，リンク重みは少しずつ 異なるものの，同型の構造が得られた。

何も構造情報がなく密結合ネットワークから出発す る例 1，例 2 のよう場合だけでなく，部分的に構造 やリンク重みが既知である場合でも，忘却付き一般構 造学習が有効であることを例 3 は示している。事前情 報によりネットワークの自由度が減った分だけ構造学 習が容易になる。すなわち, 本来 49 本 $(=7 \times 7)$ の学

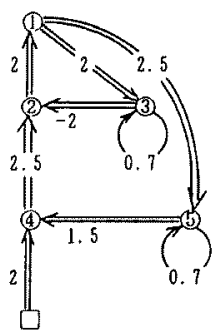

(a) 正しい椿造

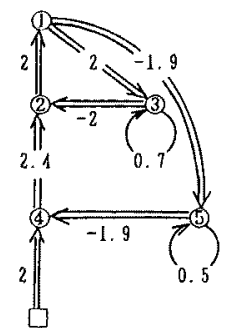

(b) 学翼結果 (ケース1)
図 5 カスケードモデルの構造再発見

Fig. 5. Rediscovery of a cascade model.

習すべきリンクがあるが，フォワードモデル部分が既 知であるため, 学習すべきリンク数は少なくなる。工 ニット数 3 のフォワードモデル部分で $9(=3 \times 3)$ 本の ところが(a)図に示すように 4 本ですを。更に, ユ一 ット(2)がフォワードモデルの入力, ユニット(1)が出力 なので, ユニット(2)(3)から(4)〜(7)への8本のリンク， およびュニット(4)〜(7)から(1)(3)への8本のリンクは考 慮しなくてすむ。このため, 学嫼すべきリンク数は $28(=49-5-8-8)$ 本となる。

(例 4) 几長性のある単純なジョルダンネットワー ク：図6 (a)に示すジョルダンネットワークから得ら れた長さ 20 の外部入力系列招よび目標出力系列に基 づいて、その構造を学習する。このネットワータは残存 率が同一の状態ユニットが 2 個あるのでて長である。 1 時刻につき 5 個のユニットを用意する。外部入力口 はユニット(2)に入り，可視ユニット(1)のみが目標出力 を与えられている。

3 種類の買なる初期重みから出発して学習を行っ た。な招学習係数, モーメンタム係数, 忘却墨, 外部 入力は例 1 と同じである。20,000 50,000回の繰返し 学習により, 例 1 と同様に十分小さな出力誤差が得ら れた。結果の1例としてケース1を(b)図に示す。同 図では余分の二つのユニットが消滅し，元の構造の冗 長な部分を取去った構造が得られた。すなわち，元の 構造での冗長な状態ユニット(3)(4)の役割を、一つの 状態ュニット(3)が果たしている。このて長さを除去す るという特性は, 骨格構造を求めるという一般構造学 習らしい特性である。

(c)図に示すケース2では，正解構造とは異なる構 造が得られた。すなわち二つのユニット(3)(4)を用い て元のネットワークと等価なネットワークを生成して いる。ケース 3 は重みの值は珙なるものの，(b)図と 同型の構造が得られた。

以上では，すべての時刻において可視ユニットに対 


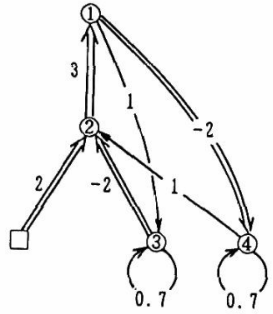

(a) 正しい構造

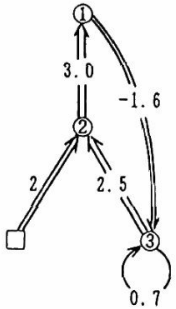

（b）学習結果（ケース1）

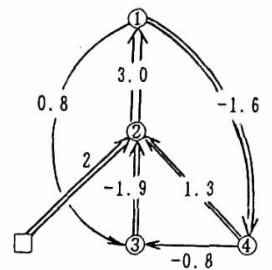

(c) 学習結果 (ケース 2)

図 6 几長なジョルダンネットワークの構造再発見

Fig. 6. Rediscovery of a redundant Jordan network.

して目標出力が与えられている場合について述べた が, (1)式での可視ュニット集合 $T(t)$ は時間的に変 動しても差し支えない。すなわち, 各時刻で可視ユ二 ット集合が変わってもよいし, 目標出力が毎時刻与え られる必要もない。例えば図 2 (a)で一時点おきに目 標出力が与えられた場合でも, 一般構造学習によりほ ほ同様な結果が得られている。

一般には，(時刻数×ユニット数）からなる集合の 部分集合に対して目標出力が与えられればよい。もち ろん，この部分集合が大きいほどより多くの情報が与 えられることに相当し, 正しい構造を再発見しやくな る。例えば，系列長が長くなったり，ユニット中の可 視ユニット数が增えることがこれに相当する。ただ し，系列長が長くなることは，階層数およびュニット 数が増大することを意味し, 学習に要する計算時間の 更なる増大をもたらす。

\section{5.むすび}

ここで提案した忘却付き一般構造学習法は, 構造に 関する事前情報なしに, 入出力系列からその構造を見 つけ出す方法である。ここでは, 正解の構造がある場 合のジョルダンネットワーク構造の再発見という課題 に適用し，その有効性を確認できた。

ここでの学習は, 入出力系列に基づいて, これらを 再現するできるだけ単純な構造を求めることに相当す るので, 未知構造の同定ととらえることもできる。各 ユニットの特性がシグモイド形という特殊な非線形性 を有することを除けば, 構造に関して何らの仮定を必 要としないノンパラメトリックな同定ともいえる。

ただ現実には, 膨大なユニットで構成される超多層 ネットワークになるので, 計算量が通常の誤差逆伝播 学習に比べて析違いに多く，比較的単純なケースでな いときれいな構造が出現しないなど, 今後に残された
課題も多い。

もつと複雑な課題に適用するには，まず比較的単純 な課題に対して構造を発見し, 得られた構造的知見を 複雑な課題に拡張して構造的制約を導入することによ り, 忘却付き一般構造学習を適用しやくするなど様々 な工夫が必要と考えられる。

(平成 3 年 9 月 4 日受付)

\section{文献}

(1) D. E. Rumelhart, J. L. McClelland \& the PDP Research Group: Parallel Distributed Processing, 1 \& 2 (1986) The MIT Press

(2) M. I. Jordan: "Generic constraints on under-specified target trajectories", International Joint Conference on Neural Networks, p. I217-225, Washington D. C. (1989)

(3) R. J. Williams \& D. Zipser: "Gradient-based learning algorithm for recurrent networks", to appear in Y. Chauvin \& D. E. Rumelhart eds., "Back-propagation : Theory, Architectures and Applications", Erlbaum.

（4）石川：「忘却を用いたコネクショニストモデルの構造学習了 ルゴリズム」, 人工知能学誌，5, No. 5, 595 (平 2)

（5）石川：「コネクショニストモデルの忘却を用いた一般構造学 習」，信学技報, $\mathrm{NC} 89-99$ (平 2)

（6）石川：「ネットワーク学習アルゴリスムの最近の課題」, 計 測と制御, 30, No. 4, 285 (平 3)

（7）石川：「コネクショニズムと学習」, 認知科学の発展, 4,51 (平 3)

（8）石川：「忘却付き構造学習の理論的·実験的検討」, 神経回路 学会第 2 回全大, p. 87 (平 3)

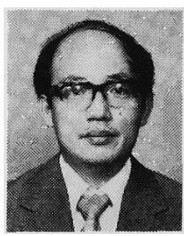

石 川眞 澄 (正員)

昭 49 年東京大学大学院博士課程修了。 同年電子技術総合研究所入所。61 62 年カリフォルニア大学客員研究員。平成 2 年九州工業大学情報工学部教授。現在 に至る。工学博士。ニューラルネットワークに関する研究 に従事。5 6 年電気学会論文賞受賞。人工知能学会, 神経 回路学会会員。 